\title{
Determination and comparison of digestion kinetics of two fibre sources in geese (Anseris)
}

\author{
Yu-Jie Lou ${ }^{1,2}$, Hong-Liang Liu ${ }^{2}$, Jun Wang ${ }^{3}$ and Zhen-Jun Sun ${ }^{1 \#}$ \\ ${ }^{1}$ College of Resources and Environmental Sciences, China Agricultural University, Beijing, 100094, China \\ ${ }^{2}$ College of Animal Science and Technology, Jilin Agricultural University, Changchun, 130118, China \\ ${ }^{3}$ College of Animal Husbandry and Veterinary Medicine, Liaoning Medical University, Jinzhou, 121001, China
}

\begin{abstract}
The aim of this study was to determine and compare the digestion kinetics of two fibre sources (lucerne, maize stalk) in different segments of the digestive tract of geese. Sixty Jilin nongan white geese were divided into two groups and fed with a lucerne or maize stalk diet. After 30 days of feeding, all of the geese were fed with Co-EDTA as the marker of liquid digesta, and n-alkane was used as an internal marker. At $1.0 \mathrm{~h}, 2.0 \mathrm{~h}, 3.0 \mathrm{~h}, 4.0 \mathrm{~h}$ and $5.0 \mathrm{~h}$ after Co-EDTA was fed, five geese per treatment per time period were sacrificed by cervical dislocation. Content of the glandular stomach, gizzard, duodenum, jejunum, ileum, caecum and rectum were collected for the evaluation of the parameters of digestion kinetics. The results showed that digestion kinetics of fibre in geese fed with a lucerne diet is consistent with that of a maize stalk diet. Within the digestive tract, digesta flow was the highest in the jejunum, and the slowest in the gizzard. Mean retention time of the digesta was the longest in the gizzard and duodenum. The digestibility of NDF, $\mathrm{ADF}$ and HC was the highest in duodenum, gizzard and duodenum and caecum respectively. Collectively, these findings suggest that the gizzard and duodenum might play important roles in the digestion of crude fibre in geese.
\end{abstract}

Keywords: Goose, fibre, lucerne, maize stalk, digestion flow markers, n-alkanes, Co-EDTA

\#Corresponding author. E-mail: zhenjunsun@126.com

${ }^{2}$ Present postal address of authors

\section{Introduction}

In recent years much interest has been devoted to the study of exploiting roughage resource. The key to utilizing roughages is digestion and absorption of the fibrous matter. The goose, a herbivorous poultry, is capable of utilizing a large amount of fibre. Natural and cultivated pastures, therefore, represent substantial food resources for the goose. In order to utilize roughage resource efficiently, the mechanism for digesting fibre in the goose should be known. However, until now, the mechanism is not fully understood.

The movement of feed through the digestive tract of animals is a dynamic process. The digestibility of nutrients is affected by many factors such as digesta flow and mean retention time (MRT), which are important parameters of digestion kinetics. The study of digestion kinetics is often used in animal nutrition, which can reflect movement rules and the characteristics of feed in the digestive tract.

Presently, cobalt (Co-EDTA) and n-alkanes are some of the most used markers in the study of digestion kinetics. Mayes \& Lamb (1984) first suggested the use of n-alkanes as markers in animal feeding studies. The n-alkanes are naturally found in the cuticular wax of plants. They have a strong affinity for solid digesta and a high recovery rate can be obtained. The advantage of n-alkanes over traditional marker substances is that there is no need for marker preparation. Recently, n-alkanes have been used in studies on digestibility, diet intake, food selection and digesta kinetics in mammals and birds (Dove \& Mayes, 1996; Hameleers et al., 1996; Hatt et al., 1998; 2001; Stevens et al., 2002).

Little quantitative information is available on the digestion of fibre in the different segments of the digestive tract of the goose. The aim of this study was to determine and compare the digestion kinetics of two fibre sources, lucerne and maize stalk, in geese using an n-alkane as internal marker of the solid phase of the digesta and Co-EDTA as the marker of the liquid phase of the digesta. 


\section{Materials and Methods}

Two diets were formulated to contain lucerne hay and maize stalk as the unique fibre sources, mixed with a concentrate according to the NRC (1994). The concentrate was based on maize, soyabean meal, wheat bran, fish meal and premix. To obtain the same level of crude fibre, lucerne and maize stalk were supplemented at different proportions. The two diets contained the same level of protein and energy. Formulation and nutrient compositions of the experiment diets are shown in Table 1. The composition of lucerne and maize stalk are shown in Table 2. The crude protein (CP) and crude fibre (CF) levels were determined according to standard AOAC (1990) procedures. The techniques described by Van Soest et al. (1991) were used to determine neutral detergent fibre (NDF) and acid detergent fibre (ADF) concentrations, and hemicelluloses (HC) was estimated by difference (NDF-ADF).

Table 1 Formulation and nutrient compositions of the experimental diet

\begin{tabular}{|c|c|c|c|c|c|}
\hline Ingredient (\%) & $\begin{array}{c}\text { Lucerne } \\
\text { diet }\end{array}$ & $\begin{array}{c}\text { Maize stalk } \\
\text { diet }\end{array}$ & Nutrient composition & $\begin{array}{c}\text { Lucerne } \\
\text { diet }\end{array}$ & $\begin{array}{c}\text { Maize stalk } \\
\text { diet }\end{array}$ \\
\hline Maize meal & 54 & 58 & $\mathrm{ME}^{2}(\mathrm{MJ} / \mathrm{kg})$ & 10.2 & 10.0 \\
\hline Soyabean meal & 12 & 15 & Crude protein (g/kg DM) & 150.8 & 150.3 \\
\hline Wheat bran & 4 & 4 & Crude fibre (g/kg DM) & 70.4 & 72.0 \\
\hline Fish meal & 2 & 2 & NDF (g/kg DM) & 178.6 & 273.8 \\
\hline Lucerne & 23 & - & ADF (g/kg DM) & 116.8 & 138.5 \\
\hline Maize stalk & - & 16 & $\mathrm{HC}(\mathrm{g} / \mathrm{kg} \mathrm{DM})$ & 61.8 & 135.3 \\
\hline Premix $^{1}$ & 5 & 5 & & & \\
\hline Total & 100 & 100 & & & \\
\hline
\end{tabular}

Table 2 Nutrient composition of lucerne and maize stalk

\begin{tabular}{lcc}
\hline Nutrients & Lucerne & Maize stalk \\
\hline Crude protein (g/kg DM) & 163 & 92 \\
Crude fibre (g/kg DM) & 244 & 309 \\
NDF (g/kg DM) & 436.5 & 653.4 \\
ADF (g/kg DM) & 254.0 & 272.8 \\
HC 1 (g/kg DM) & 182.5 & 280.6 \\
\hline
\end{tabular}

Sixty healthy female and male Jilin nongan white geese (five wk old) roughly of the same weight were divided into two groups of 30 according to a completely randomized design. One group was fed diet containing the lucerne, and the other the diet with the maize stalk. The geese were housed at the farming base of Jilin Agricultural University. The birds were fed three times daily and had free access to water. Ethical approval for the study was obtained from the Ethical Committee at Jilin Agricultural University, China. 
After a feeding period of 30 days, the geese received $0.2 \mathrm{~g}$ Co-EDTA/bird through the diet, and nalkane $\left(\mathrm{C}_{29}\right)$ was used as an internal marker. At $1.0 \mathrm{~h}, 2.0 \mathrm{~h}, 3.0 \mathrm{~h}, 4.0 \mathrm{~h}$ and $5.0 \mathrm{~h}$ after marker administration five geese per treatment at each time period were sacrificed by cervical dislocation. The content of the glandular stomach, gizzard, duodenum, jejunum, ileum and rectum were collected. These samples were frozen at $-20^{\circ} \mathrm{C}$ for $48 \mathrm{~h}$, and subsequently freeze-dried to a constant mass for the determination of marker concentrationat each time point. The samples collected at $5 \mathrm{~h}$ after marker administration were also used to determine the digestibility of the fibre fractions in the different segments of the digestive tract.

The preparation of Co-EDTA, the marker of liquid digesta, was done according to Uden (1980). The alkane, $\mathrm{C}_{29}$, was used as the marker of solid digesta and digestibility. The concentration of n-alkanes was determined using gas chromatography (HP 5890 Series II), according to the method reported by Mayes et al. (1986), with $\mathrm{C}_{34}$ as an external analytical standard.

One gram of digesta was weighed into a $50 \mathrm{~mL}$ serum bottle. Then $0.5 \mathrm{mg}$ external standard $\left(\mathrm{C}_{34}\right)$ and $10 \mathrm{~mL}$ ethanolic $\mathrm{KOH}(1.5 \mathrm{~mol} / \mathrm{L})$ were added to the bottle. The bottle was then capped and heated for $4.5 \mathrm{~h}$ at $90{ }^{\circ} \mathrm{C}$ in a heating oven. After cooling to $50-60{ }^{\circ} \mathrm{C}$, the solution in the bottle was mixed with $7 \mathrm{~mL}$ of $\mathrm{n}$ heptane and $5 \mathrm{~mL}$ of deionized water. The supernatant was transferred to a test tube after being centrifuged for $5 \mathrm{~min}(2000 \mathrm{r} / \mathrm{min})$. The final solution was filtered and purified by $2 \mathrm{~g}$ of silica gel, and the tube was washed repeatedly with $10 \mathrm{~mL}$ of n-heptane, where-upon the solution was evaporated to dryness. Finally, the purified n-alkanes were dissolved with $1 \mathrm{~mL}$ of $\mathrm{n}$-heptane and the solution was loaded onto a gas chromatograph for the determination of the concentration of the n-alkanes.

1. The following equation was used to calculate the liquid digesta flow $(\mathrm{Q}, \mathrm{mg} / \mathrm{h})$ :

Where:

$$
\mathrm{Q}=\mathrm{M} \text { dosed } / \mathrm{C}_{0}
$$

M dosed is the amount of the marker dosed (Co-EDTA).

$\mathrm{C}_{0}$ is the marker concentration of digesta in each digestive tract at zero time.

2. The digesta flow rate $(\% / h)$ was calculated with the following equation:

Where:

$\mathrm{C}=\mathrm{Co}^{*} \mathrm{e}^{-\mathrm{kt}}$

$\mathrm{C}(\mathrm{mg} / \mathrm{kg})$ is the marker concentration at the time of sampling;

$\mathrm{C}_{0}$ is the marker concentration of digesta in each digestive tract at zero time;

$k$ is the digesta flow rate $(\% / h)$;

$t$ is the sampling time after marker administration.

3. $\mathrm{MRT}=1 / \mathrm{k}$

$k$ is the digesta flow rate $(\% / \mathrm{h})$.

4. The flow of fibre fractions (NDF, ADF and HC) of digesta in the different segments of digestive tracts was calculated with the following equation:

Where:

$\mathrm{Q}(\mathrm{NDF}, \mathrm{ADF}, \mathrm{HC})=\mathrm{G} * \mathrm{Q}$

$\mathrm{Q}$ (NDF, ADF, HC) is the flow of fibre fraction (NDF, ADF, HC);

$\mathrm{G}$ is the concentration of the fibre fraction (NDF, ADF, HC) in the digesta;

$\mathrm{Q}$ is the digesta flow in different segments of digestive tract.

5. Digestibility (\%) was calculated using the following equation:

Where:

Digestibility $(\%)=100-100 *$ bc/ad

a is the content of nutrient in feed;

$\mathrm{b}$ is the content of nutrient in digesta;

$\mathrm{c}$ is the content of marker in feed;

$\mathrm{d}$ is the content of marker in digesta.

Data was analyzed using the SPSS 13.0 for windows statistical software (SPSS, 2004). Differences in digestion kinetics and digestibility of fibres in the different segments of the digestive tract were tested for statistical significance using ANOVA and Multiple comparisons. 


\section{Results}

The results of the digesta flow and digesta flow rate in the digestive tract are shown in Table 3. For the two diets, the digesta flow was the highest in the jejunum $(\mathrm{P}<0.05)$ and the lowest in the gizzard. The liquid digesta flow was higher than that of solid digesta in different segments of the digestive tract. The digesta flow for lucerne diet was higher than that of maize stalk diet in the same segments of the digestive tract $(\mathrm{P}<0.05)$.

Table 3 Digesta flow and flow rate in the different segments of the digestive tract of geese

\begin{tabular}{|c|c|c|c|c|c|c|c|c|}
\hline \multirow{3}{*}{$\begin{array}{c}\text { Digestive } \\
\text { tract }\end{array}$} & \multicolumn{4}{|c|}{ Digesta flow ( g/h ) } & \multicolumn{4}{|c|}{ Flow rate $(\% / h)$} \\
\hline & \multicolumn{2}{|c|}{ Maize stalk diet } & \multicolumn{2}{|c|}{ Lucerne diet } & \multicolumn{2}{|c|}{ Maize stalk diet } & \multicolumn{2}{|c|}{ Lucerne diet } \\
\hline & liquid & solid & liquid & solid & liquid & solid & liquid & solid \\
\hline $\begin{array}{l}\text { Glandular } \\
\text { stomach }\end{array}$ & $\begin{array}{c}0.18^{\mathrm{b}} \\
\pm 0.05\end{array}$ & $\begin{array}{c}0.13^{\mathrm{b}} \\
\pm 0.04\end{array}$ & $\begin{array}{c}0.39^{\mathrm{b}} \\
\pm 0.08\end{array}$ & $\begin{array}{c}0.28^{\mathrm{c}} \\
\pm 0.12\end{array}$ & $\begin{array}{c}0.60^{\mathrm{a}} \\
\pm 0.45\end{array}$ & $\begin{array}{c}0.62^{\mathrm{a}} \\
\pm 0.19\end{array}$ & $\begin{array}{c}0.44^{\mathrm{a}} \\
\pm 0.06\end{array}$ & $\begin{array}{r}0.32^{\mathrm{a}} \\
\pm 0.08\end{array}$ \\
\hline Gizzard & $\begin{array}{c}0.21^{\mathrm{b}} \\
\pm 0.02\end{array}$ & $\begin{array}{l}0.17^{\mathrm{b}} \\
\pm 0.04\end{array}$ & $\begin{array}{c}0.41^{\mathrm{b}} \\
\pm 0.13\end{array}$ & $\begin{array}{c}0.30^{\mathrm{c}} \\
\pm 0.02\end{array}$ & $\begin{array}{c}0.34^{\mathrm{c}} \\
\pm 0.56\end{array}$ & $\begin{array}{c}0.31^{\mathrm{c}} \\
\pm 0.07\end{array}$ & $\begin{array}{c}0.27^{\mathrm{c}} \\
\pm 0.04\end{array}$ & $\begin{array}{r}0.19^{\mathrm{d}} \\
\pm 0.12\end{array}$ \\
\hline Duodenum & $\begin{array}{c}0.24^{\mathrm{b}} \\
\pm 0.03\end{array}$ & $\begin{array}{c}0.25^{\mathrm{a}} \\
\pm 0.19\end{array}$ & $\begin{array}{l}0.45^{\mathrm{b}} \\
\pm 0.23\end{array}$ & $\begin{array}{c}0.31^{\mathrm{b}} \\
\pm 0.04\end{array}$ & $\begin{array}{c}0.36^{\mathrm{c}} \\
\pm 0.03\end{array}$ & $\begin{array}{c}0.31^{\mathrm{c}} \\
\pm 0.29\end{array}$ & $\begin{array}{c}0.31^{\mathrm{c}} \\
\pm 0.02\end{array}$ & $\begin{array}{c}0.18^{\mathrm{d}} \\
\pm 0.06\end{array}$ \\
\hline Jejunum & $\begin{array}{c}0.30^{\mathrm{a}} \\
\pm 0.08\end{array}$ & $\begin{array}{c}0.29^{\mathrm{a}} \\
\pm 0.05\end{array}$ & $\begin{array}{c}0.52^{\mathrm{a}} \\
\pm 0.22\end{array}$ & $\begin{array}{c}0.37^{\mathrm{a}} \\
\pm 0.04\end{array}$ & $\begin{array}{l}0.54^{\mathrm{ab}} \\
\pm 0.08\end{array}$ & $\begin{array}{c}0.40^{\mathrm{b}} \\
\pm 0.06\end{array}$ & $\begin{array}{c}0.35^{\mathrm{b}} \\
\pm 0.19\end{array}$ & $\begin{array}{c}0.37^{\mathrm{c}} \\
\pm 0.19\end{array}$ \\
\hline Ileum & $\begin{array}{c}0.27^{\mathrm{b}} \\
\pm 0.03\end{array}$ & $\begin{array}{c}0.24^{\mathrm{a}} \\
\pm 0.03\end{array}$ & $\begin{array}{c}0.52^{\mathrm{b}} \\
\pm 0.18\end{array}$ & $\begin{array}{l}0.33^{\mathrm{ab}} \\
\pm 0.07\end{array}$ & $\begin{array}{c}0.52^{\mathrm{b}} \\
\pm 0.08\end{array}$ & $\begin{array}{c}0.32^{\mathrm{c}} \\
\pm 0.04\end{array}$ & $\begin{array}{c}0.32^{\mathrm{b}} \\
\pm 0.05\end{array}$ & $\begin{array}{c}0.22^{\mathrm{c}} \\
\pm 0.07\end{array}$ \\
\hline Caecum & $\begin{array}{c}0.26^{\mathrm{b}} \\
\pm 0.04\end{array}$ & $\begin{array}{c}0.21^{\mathrm{b}} \\
\pm 0.06\end{array}$ & $\begin{array}{c}0.48^{\mathrm{b}} \\
\pm 0.06\end{array}$ & $\begin{array}{c}0.35^{\mathrm{a}} \\
\pm 0.03\end{array}$ & $\begin{array}{c}0.39^{c} \\
\pm 0.19\end{array}$ & $\begin{array}{c}0.32^{\mathrm{C}} \\
\pm 0.19\end{array}$ & $\begin{array}{c}0.31^{\mathrm{c}} \\
\pm 0.08\end{array}$ & $\begin{array}{l}0.22^{\mathrm{cd}} \\
\pm 0.04\end{array}$ \\
\hline Rectum & $\begin{array}{c}0.23^{\mathrm{b}} \\
\pm 0.05\end{array}$ & $\begin{array}{c}0.19^{\mathrm{b}} \\
\pm 0.08\end{array}$ & $\begin{array}{c}0.43^{\mathrm{b}} \\
\pm 0.05\end{array}$ & $\begin{array}{c}0.31^{\mathrm{a}} \\
\pm 0.05\end{array}$ & $\begin{array}{c}0.54^{\mathrm{b}} \\
\pm 0.01\end{array}$ & $\begin{array}{c}0.69^{\mathrm{a}} \\
\pm 0.06\end{array}$ & $\begin{array}{c}0.51^{\mathrm{b}} \\
\pm 0.04\end{array}$ & $\begin{array}{c}0.52^{\mathrm{b}} \\
\pm 0.05\end{array}$ \\
\hline
\end{tabular}

a-d Digesta flow and flow rate not sharing the same superscript are significantly different within different segments of the digestive tracts; $\mathrm{P}<0.05$.

The results of MRT of digesta in the digestive tract of the geese are presented in Figure 1. The MRT of digesta was higher for the gizzard and duodenum than the other segments of the digestive tract. In the lucerne diet group, the MRT of solid digesta in the gizzard and duodenum was higher than that in other segments of the digestive tract $(\mathrm{P}<0.05)$, while in the maize stalk diet group, it did not differ $(\mathrm{P}>0.05)$. For the two diets, MRT of liquid digesta in gizzard was significantly higher than that in other segments of the digestive tract. The MRT of digesta in different segments of the digestive tract in the lucerne diet group was higher than that in the maize stalk diet group $(\mathrm{P}<0.05)$.

The results of digesta flow of the fibre fraction in the different segments of the digestive tract are presented in Table 4. In the lucerne diet group, digesta flow of NDF in duodenum and jejunum was higher than that in the lower digestive tract $(\mathrm{P}<0.05$ ), while there was no difference in the maize stalk diet group ( $\mathrm{P}$ $>0.05$ ). Digesta flow of ADF in the gizzard was higher than that in the other segments of the digestive tract, but the difference was not significant. For the two diets, the digesta flow of HC in the caecum was higher than that in the jejunum, ileum and rectum $(\mathrm{P}<0.05)$.

The results of digestibility of NDF, ADF and HC in different segments of digestive tracts are shown in Figure 2. The digestibility of NDF and ADF in the lucerne diet group was higher than those in the maize stalk diet group. The digestibility of NDF in duodenum and jejunum was higher than that in the other 
segments of the digestive tract $(\mathrm{P}<0.05)$. The digestibility of ADF in gizzard and duodenum was higher than that in the other segments of the digestive tract $(\mathrm{P}<0.05)$, and the digestibility of HC was highest in caecum.

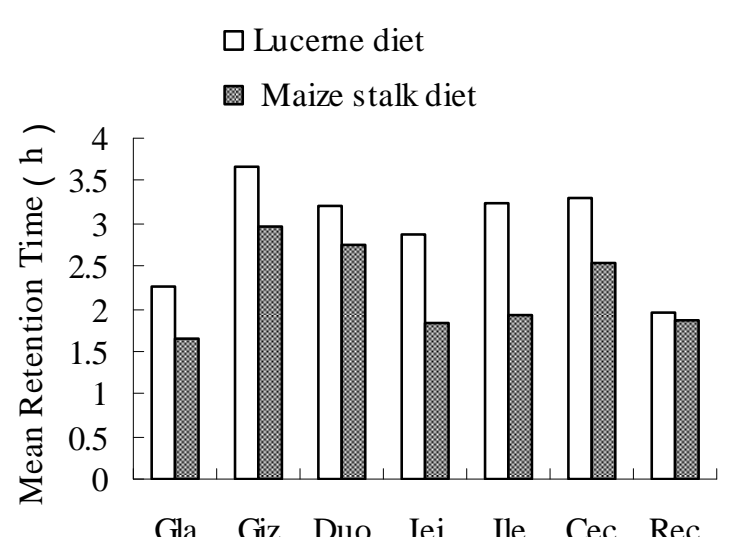

(a)

Digestive Tract

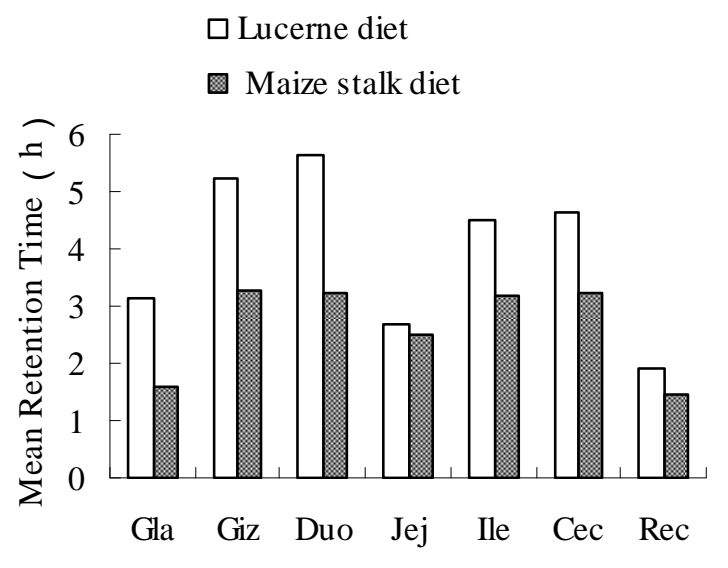

(b)

Digestive Tract

Figure 1 Mean retention time (MRT) of liquid digesta (a) and solid digesta (b) in the glandular stomach (Gla), gizzard (Giz), duodenum (Duo), jejunum (Jej), ileum (Ile), caecum (Cec) and rectum (Rec) of geese fed diets containing lucerne or maize stalk.

Table 4 Digesta flow (g/h) of fibre fractions (NDF, ADF and HC) in different segments of digestive tracts

\begin{tabular}{lcccccc}
\hline \multirow{2}{*}{ Digestive tract } & \multicolumn{3}{c}{ Maize stalk diet } & \multicolumn{3}{c}{ Lucerne diet } \\
\cline { 2 - 7 } & NDF & ADF & HC & NDF & ADF & HC \\
\hline \multirow{2}{*}{ Glandular } & & & & & & \\
stomach & $0.02^{\mathrm{ns}}$ & $0.14^{\mathrm{ns}}$ & $0.06^{\mathrm{a}}$ & $0.11^{\mathrm{a}}$ & $0.07^{\mathrm{ns}}$ & $0.05^{\mathrm{a}}$ \\
& \pm 0.00 & \pm 0.03 & \pm 0.01 & \pm 0.02 & \pm 0.03 & \pm 0.03 \\
Gizzard & $0.03^{\mathrm{ns}}$ & $0.15^{\mathrm{ns}}$ & $0.07^{\mathrm{a}}$ & $0.11^{\mathrm{a}}$ & $0.11^{\mathrm{ns}}$ & $0.05^{\mathrm{a}}$ \\
& \pm 0.01 & \pm 0.03 & \pm 0.02 & \pm 0.06 & \pm 0.06 & \pm 0.01 \\
Duodenum & $0.05^{\mathrm{ns}}$ & $0.13^{\mathrm{ns}}$ & $0.07^{\mathrm{a}}$ & $0.16^{\mathrm{a}}$ & $0.07^{\mathrm{ns}}$ & $0.05^{\mathrm{a}}$ \\
& \pm 0.03 & \pm 0.02 & \pm 0.02 & \pm 0.03 & \pm 0.05 & \pm 0.02 \\
Jejunum & $0.05^{\mathrm{ns}}$ & $0.14^{\mathrm{ns}}$ & $0.05^{\mathrm{a}}$ & $0.15^{\mathrm{a}}$ & $0.04^{\mathrm{ns}}$ & $0.03^{\mathrm{b}}$ \\
& \pm 0.04 & \pm 0.03 & \pm 0.01 & \pm 0.01 & \pm 0.03 & \pm 0.00 \\
Ileum & $0.04^{\mathrm{ns}}$ & $0.11^{\mathrm{ns}}$ & $0.04^{\mathrm{a}}$ & $0.04^{\mathrm{b}}$ & $0.02^{\mathrm{ns}}$ & $0.02^{\mathrm{b}}$ \\
& \pm 0.01 & \pm 0.04 & \pm 0.02 & \pm 0.01 & \pm 0.01 & \pm 0.00 \\
Caecum & $0.02^{\mathrm{ns}}$ & $0.12^{\mathrm{ns}}$ & $0.08^{\mathrm{ab}}$ & $0.04^{\mathrm{b}}$ & $0.04^{\mathrm{ns}}$ & $0.06^{\mathrm{a}}$ \\
& \pm 0.01 & \pm 0.02 & \pm 0.08 & \pm 0.01 & \pm 0.03 & \pm 0.01 \\
Rectum & $0.02^{\mathrm{ns}}$ & $0.11^{\mathrm{ns}}$ & $0.02^{\mathrm{b}}$ & $0.03^{\mathrm{c}}$ & $0.01^{\mathrm{ns}}$ & $0.01^{\mathrm{c}}$ \\
& \pm 0.01 & \pm 0.03 & \pm 0.00 & \pm 0.00 & \pm 0.01 & \pm 0.01 \\
\hline
\end{tabular}

NDF - neutral detergent fibre; ADF - acid detergent fibre; HC - hemicelluloses.

ns: Digesta flow of fibre fraction sharing the superscript is not significantly different within different segments of the digestive tract, $\mathrm{P}<0.05$.

a-c: Digesta flow of fibre fraction not sharing the same superscript is significantly different within different

segments of the digestive tract, $\mathrm{P}<0.05$. 

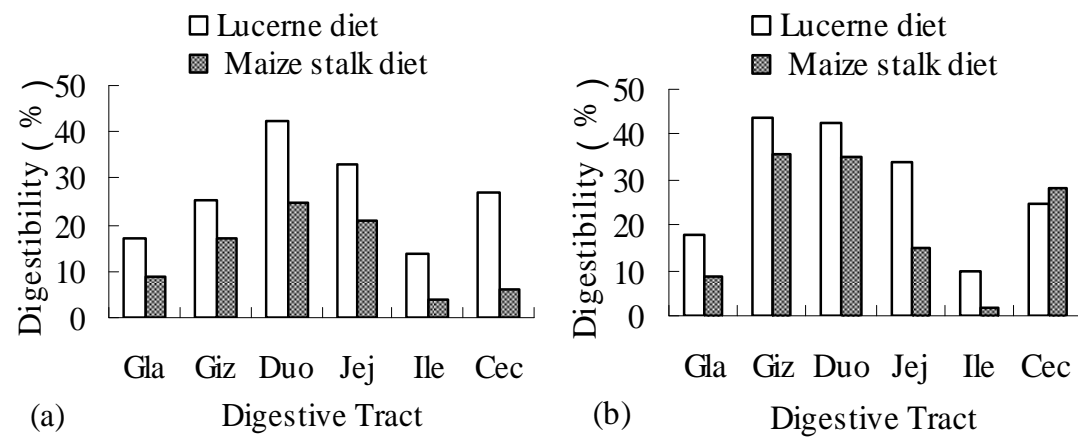

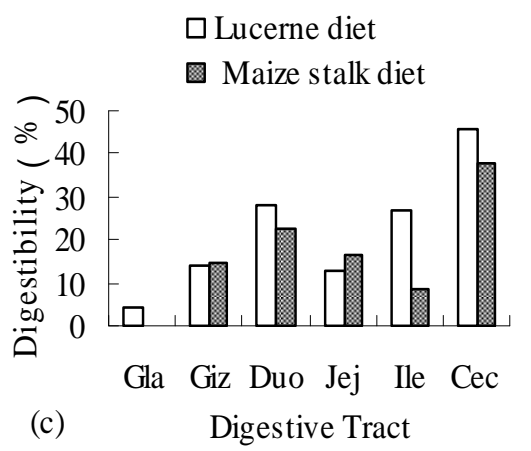

Figure 2 Digestibility of neutral detergent fibre (NDF) (a), acid detergent fibre (ADF) (b) and hemicelluloses (HC) (c) in the glandular stomach (Gla), gizzard (Giz), duodenum (Duo), jejunum (Jej), ileum (Ile), caecum (Cec) and rectum (Rec) of geese fed diets containing lucerne or maize stalk.

\section{Discussion}

The flow rate of roughage in the gastrointestinal tracts of animals varies because roughages contain different level of fibres. In the present study on two fibre sources, liquid digesta flow in the different segments of the digestive tract of the geese was higher than solid digesta flow. Lucerne, as a high quality forage crop contains much soluble substances than maize stalk. Therefore the proportion of liquid digesta in the gastrointestinal tracts of animals was higher for lucerne than that for maize stalk diets. Consequently, solid and liquid digesta flow of the lucerne diet group were higher than those of the maize stalk diet group. Digesta flow in the jejunum was higher than that in other segments of the digestive tract. It could be due to the fact that viscous fibre can stabilize the digesta and prevent separation of the solid from the liquid phase, impairing the retention of the larger particles, and thereby causing the digesta flow in jejunum to be increased.

The velocity of diet passing the digestive tract is a crucial digestion parameter. Maize stalk contains more fibre than lucerne, and in this study the digesta flow rate of the maize stalk diet was higher than that of the lucerne diet. It might be due to the fact that peristalsis of the gastrointestinal tract increases as fibre content increases and thereby causing the digesta flow rate to be increased. In this study, the digesta flow rate was higher and the MRT of digesta was the longest in the gizzard and duodenum. These results illustrate that digesta need to be ground and mixed adequately in the gizzard so that it can be thoroughly digested and absorbed in the duodenum.

The results of the present study demonstrated that the digestibility of NDF, ADF and HC was the highest in the duodenum, gizzard and duodenum, and in the caecum respectively. The digestibility of crude fibre in geese is controversial. Marriott \& Forbes (1970) found that the digestibility of crude fibre of Cape Barren geese fed with lucerne chaff was $0.8 \%$. However, Hollister et al. (1984) reported that the digestibility of crude fibre was $21.4 \%$ when the geese were fed a diet containing $40 \%$ lucerne meal. It also has been reported that the goose could digest 28\% cellulose and 25\% hemicellulose from plants (Buchsbaum et al., 1986). Shao (1991) found that the digestibility of hemicellulose, NDF and ADF was $41.5 \%, 37.4 \%$ and 21.7\% respectively, while Timmler (1994) reported that fibre would be digested, depending on the composition of the diet: NDF by $21.4 \%$ to $40.9 \%$, ADF by $5.5 \%$ to $31.7 \%$, hemicellulose by $27.5 \%$ to $90.5 \%$ and cellulose by $10.1 \%$ to $32.0 \%$. These studies demonstrated that geese could utilize a certain proportion of dietary crude fibre. However, these results are inconsistent probably caused of differences in breed and age of the geese, fibre sources, plant maturity, season, nutrient concentration of diets, etc.

The digestive mechanism of dietary fibre in geese is still not fully understood, especially digestive sites. It has been suggested that the caecum, where cellulase was detected, plays an important role in crude fibre digestion in geese (Chiou et al., 1994; Wang et al., 2004; Zhou, 2004). However, opposite results were also reported. Mattocks et al. (1971) pointed out that there was no cellulase in the caecum of geese. Hallsworth \& Coates (1962) also maintained that the caecum does not play an important role in crude fibre digestion in geese because the caecum of geese is smaller than in other poultry species. Shao \& Han (1992) 
found that the digestion of cellulose decreased after reaching the caecum of geese. However, they considered that the caecum does not play a crucial role in the digestion of crude fibre, because the digesta in the caecum is less than in the rest of the digestive tracts. Timmler (1994) also concluded that the role of the caecum in crude fibre digestion in geese needs further investigation. Interestingly, Chen (2006) detected hemicellulase and cellulase in the duodenum, jejunum, ileum and caecum, and hemicellulase activity was the highest in the duodenum. Furthermore, our laboratory recently demonstrated the occurrence of colonization of flora in the digestive tract of geese and found that the dominant flora of the duodenum were lactobacillus and bifidobacteria (Cui et al., 2008). With the use of duodenal cannulae Shao (1991) found that $13.6 \%$ of the hemicellulose and $10.7 \%$ of the NDF were digested before the digesta reached the duodenum. Chiou et al. (1994) and Yang (1995) demonstrated that the feeding of a high fibre diet could promote the development of the gizzard and caecum. These observations suggest that the ability of geese to digest high fibre diets might be due to the combined action of the gizzard, small intestine and large intestine.

It can be concluded that digestion kinetics of fibre in geese fed a lucerne diet is consistent with that of a maize stalk diet. The results also suggest that the gizzard and duodenum might play important roles in digestion of fibre in geese. However, it will require more investigations before a full explanation of the digestive mechanism in the goose would be forthcoming.

\section{References}

AOAC, 1990. Official Methods of Analysis (15th ed). Association of Official Analytical Chemists, Inc., Arlington, Virginia, USA.

Buchsbaum, R., Wilson, J. \& Valiela, I., 1986. Digestibility of plant constituents by Canada geese and Atlantic brant. Ecology 67, 386-393.

Chen, W.H., 2006. Utilization and digestion of different sources dietary fiber in Yangzhou Goose. Master thesis, Yangzhou University, China.

Chiou, P.W., Yu, B. \& Lin, C., 1994. Effect of different components of dietary fiber on the intestinal morphology of domestic rabbits. Comp. Biochem. Physiol. Comp. Physiol. 108, 629-638.

Cui, X.Y., Wang, C.W. \& Liu, M., 2008. Study on the law of colonization of main normal flora in geese's digestive tract. J. China Poult. 30, 17-24.

Dove, H., 1992. Using the n-alkanes of plant cuticular wax to estimate the species composition of herbage mixture. Aust. J. Agric. Res. 43, 1711-1724.

Dove, H. \& Mayes, R.W., 1996. Plant wax components: a new approach to estimating intake and diet composition in herbivores. J. Nutr. 126, 13-26.

Hallsworth, E.G. \& Coates, J.I., 1962. The growth of the alimentary tract of the fowl and the goose. J. Agric. Sci. 58, 153-163.

Hameleers, A., Mcnab, J. \& Mayes, R.W., 1996. Use of saturated aliphatic hydrocarbons (alkanes) as markers in nutrition studies in chickens. Br. Poult. Sci. 37, 105-106.

Hatt, J.M., Lechner-Doll, M. \& Mayes, B., 1998. The use of n-alkanes as markers for determination of digestive strategies of captive giraffes (Giraffa camelopardalis). Zoo Biol. 17, 295-309.

Hatt, J.M., Mayes, R.W., Clauss, M. \& Echner-Doll, M., 2001. Use of artificially applied n-alkanes as markers for the estimation of digestibility, food selection and intake in pigeons (Columba livia). Anim. Feed Sci. Technol. 94, 65-76.

Hollister, A.G., Nakaue, H.S. \& Arscott, G.H., 1984. Studies with confinement reared goslings.1. Effects of feeding high levels of dehydrated lucerne and Kentucky bluegrass to growing goslings. Poult. Sci., 63, 532-537.

Marriott, R.W. \& Forbes, D.K., 1970. The digestion of lucerne chaff by Cape Barren geese, Cereopsis novaehollandiae Latham. Aust. J. Zool. 18, 257-263.

Mattocks, J.G., 1971. Goose feeding and cellulose digestion. Wildfowl 22, 107-113.

Mayes, R.W. \& Lamb, C.S., 1984. The possible use of n-alkanes in herbage as indigestible faecal markers. Proc. Nutr. Soc. 43, 39A.

Mayes, R.W., Lamb, C.S. \& Colgrove, P.M., 1986. The use of dosed and herbage n-alkane as markers for the determination of herbage intake. J. Agric. Sci., Camb. 107, 161-170.

NRC, 1994. Nutrient Requirements of Poultry (9th ed.). National Academy Press, Washington D.C., USA.

Shao, C.M., 1991. Study on digestive physiology of goose. PhD thesis, Nanjing Agricultural University, China. 
Shao, C.M. \& Han, Z.K., 1992. Studies on fibre components digestion of cecum in goose. J. Nanjing Agric. Univ. 15, 86-89.

SPSS, 2004. SPSS 13.0 for Windows brief guide. SPSS Inc., Chicago, USA.

Stevens, D.M., Van Ryssen, J.B.J. \& Marais, J.P., 2002. The use of n-alkane markers to estimate the intake and apparent digestibility of ryegrass and kikuyu by horses. S. Afr. J. Anim. Sci. 32, 50-56.

Stevenson, M.H., 1989. Nutrition of domestic geese. Proc. Nutr. Soc. 40, 103-111.

Timmler, R., 1994. Investigation into the digestibility of high fiber feedstuffs for geese. Proc. $8^{\text {th }}$ Int. Symp. Young Poultry Scientists. Poland.

Uden, P., Colucci, P.E. \& Van Soest, P.J., 1980. Investigations of chromium, cerium and cobalt as markers in digesta. Rate of passage studies. J. Sci. Food Agric. 31, 625-632.

Van Soest, P.J., Robertson, J.B. \& Lewis, B.A., 1991. Methods for dietary fiber, neutral detergent fiber and nonstarch polysaccharides in relation to animal nutrition. J. Dairy Sci. 74, 3583-3597.

Wang, Z.Y., Wang, J. \& Zhao, W.L., 2004. Comparison of fibre metabolic rate of different fodder diets in caecectomized and intact geese. Chinese J. Anim. Sci. 40, 16-18.

Yang, S.M., 1995. The research on utilization of fibrous feeds by goslings. Scientia Agricultural Sinica 28, 171-176.

Zhou, X.L., 2004. Study on effect of lucerne, ryegrass and wheat middlings contents in dietary on digestive physiology and performance in goslings. Master thesis, Yangzhou University, China. 